\title{
ANALISIS INVESTASI, PAD DAN JUMLAH UNIT UKM TERHADAP PENYERAPAN TENAGA KERJA UKM DI KABUPATEN LABUHANBATU
}

\section{ZULKARNAIN NASUTION}

\author{
Dosen Sekolah Tinggi Ilmu Ekonomi (STIE) Labuhanbatu
}

\section{ABSTRACK}

The purpose of this study is to analyze the effect of investment, PAD, the number of SMEs and the absorption of SMEs workforce in Labuhanbatu District. The sample was obtained from the statistics book of small and medium enterprises of Cooperative and SME Office 20072016. The analytical method in this study is Ordinary Least Square (OLS) with the help of IBM SPSS 20 computer program. The result of analysis shows that SME investment and the number of SME business unit have a significant effect on the absorption of small and medium enterprises. Meanwhile, PAD has not significant effect on the absorption of small and medium enterprises.

Keywords: Employment of SMEs, SME Investment, PAD and Number of SME Units

\begin{abstract}
ABSTRAK
Tujuan penelitian ini adalah untuk menganalisa pengaruh investasi, PAD, jumlah UKM dan penyerapan tenaga kerja UKM di Kabupaten Labuhanbatu. Sampel penelitian diperoleh dari buku statistik usaha kecil dan menengah Dinas Koperasi dan UKM tahun 2007-2016. Metode analisis yang digunakan dalam penelitian ini adalah Ordinary Least Square (OLS) dengan bantuan program komputer IBM SPSS 20. Hasil analisis menunjukan bahwa investasi UKM dan jumlah unit usaha UKM berpengaruh signifikan terhadap penyerapan tenaga kerja usaha kecil dan menengah. Sedangkan, PAD tidak berpengaruh signifikan terhadap penyerapan tenaga kerja usaha kecil dan menengah.
\end{abstract}

Kata kunci : Penyerapan Tenaga Kerja UKM, Investasi UKM, PAD dan Jumlah Unit UkM .

\section{PENDAHULUAN}

Indonesia merupakan negara yang sedang berkembang. Pembangunan ekonomi yang dilaksanakan oleh negara berkembang bertujuan memeratakan pembangunan ekonomi dan hasilnya kepada seluruh masyarakat, meningkatkan laju pertumbuhan ekonomi, meningkatkan kesempatan kerja, pemerataan pendapatan, mengurangi perbedaan kemampuan antar daerah dan struktur perekonomian yang seimbang (Sukirno, 2005: 445).

Sedangkan menurut Heatubun (2008: 25), secara umum salah satu ciri kondisi negara berkembang adalah jumlah populasi cukup tinggi dengan konsekuensi angkatan kerja yang besar dan potensi pengangguran. Tidak jauh berbeda dengan negara berkembang lainya, Indonesia juga memiliki kondisi sesuai ciri negara berkembang tersebut.

Pembangunan Ekonomi merupakan salah satu usaha untuk meningkatkan taraf hidup suatu bangsa dengan tujuan meningkatkan pendapatan nasional riil juga untuk meningkatkan produktivitas. Pembangunan ekonomi memiliki tujuan inti diantaranya peningkatan ketersediaan serta perluasan distribusi berbagai barang kebutuhan hidup, peningkatan standar hidup (pendapatan, penyediaan lapangan kerja dan perluasan pilihan-pilihan ekonomis dan 
sosial (Todaro, 2006). Pembangunan ekonomi dapat memberikan kepada manusia kemampuan yang lebih besar untuk

menguasai alam sekitarnya dan mempertinggi tingkat kebebasannya dalam mengadakan suatu tindakan tertentu termasuk didalamnya ialah pengembangan lapangan pekerjaan yang ada dimasing-masing daerah Kota maupun Kabupaten yang ada di Indonesia. Perluasan penyerapan tenaga kerja diperlukan untuk mengimbangi laju pertumbuhan penduduk usia muda yang masuk ke pasar tenaga kerja. Ketidakseimbangan antara pertumbuhan angkatan kerja dan penciptaan lapangan kerja akan menyebabkan tingginya angka pengangguran. Kemudian, meningkatnya angka pengangguran akan mengakibatkan pemborosan sumber daya dan potensi angkatan kerja yang ada, meningkatnya beban masyarakat, merupakan sumber utama kemiskinan dan mendorong terjadinya peningkatan keresahan sosial, serta manghambat pembangunan ekonomi dalam jangka panjang (Depnakertrans, 2004).

Proses kegiatan ekonomi harus tumbuh dan berkembang lebih cepat dari pertambahan jumlah orang yang mencari pekerjaan. Keadaan ini sangat diperlukan untuk memperkecil tingkat pengangguran terbuka. Dengan adanya penyerapan tenaga kerja maka penduduk atau masyarakat yang sebelumnya tidak bekerja akan mendapatkan pekerjaan yang tentunya akan memberikan penghasilan, dari penghasilan ini kemudaian akan dapat berubah menjadi konsumsi. Dengan demikian maka akan mengurangi kemiskinan, dapat mensejahterakan masyarakat yang ada khususnya di Kabupaten Labuhanbatu. Dengan lapangan pekerjaan yang cukup banyak baik di instansi pemerintah maupun swasta. Berdasarkan data Badan Pusat Statistik Kabupaten Labuhanbatu, jumlah tenaga kerja yang ada semakin meningkat secara signifikan dari tahun ke tahun hal ini dapat di lihat pada

Tabel 1.1

Penduduk Berumur 15 Tahun ke Atas yang Mencari Pekerjaan, Penduduk Berumur 15 Tahun ke Atas yang Bekerja, dan Tenaga Kerja Usaha Kecil dan Menengah (UKM)

\begin{tabular}{|l|l|l|l|}
\hline Tahun & $\begin{array}{l}\text { Penduduk yang } \\
\text { mencari pekerjaan }\end{array}$ & $\begin{array}{l}\text { Penduduk yang } \\
\text { bekerja }\end{array}$ & Tenaga kerja UKM \\
\hline 2007 & 42.048 & 361.071 & 10.567 \\
\hline 2008 & 42.291 & 396.559 & 10.839 \\
\hline 2009 & 40.890 & 419.578 & 11187 \\
\hline 2010 & 12586 & 166.131 & 11373 \\
\hline 2011 & 11.835 & 189.438 & 11547 \\
\hline 2012 & 12897 & 152.479 & 11739 \\
\hline 2013 & 17023 & 173.564 & 11547 \\
\hline 2014 & 14682 & 175.507 & 12009 \\
\hline 2015 & 20999 & 163.324 & 12273 \\
\hline 2016 & 20999 & 163.324 & 12273 \\
\hline
\end{tabular}

Sumber: Statistik Indonesia 2016 dan Dinas Koperasi dan UKM, diolah

Berdasarkan tabel 1.1 maka dapat di lihat bagaimana perkembangan angka jumlah tenaga kerja yang ada di Kabupaten Labuhanbatu pada periode Tahun 2007 sampai dengan 2016. Jumlah tenaga kerja yang ada di Kabupaten Labuhanbatu mengalami peningkatan pada tahun ke tahun, terbilang pada tahun 2007 dengan jumlah tenaga kerja sebanyak 361.071 data ini Kabupaten Labuhanbatu belum pemekaran daerah pada tahun 2012 sebanyak 152.479 jiwa serta pada tahun 2014 sebanyak 175.507 selanjutnya mengalami penurunan. Data tersebut 
menggambarkan bahwa kenaikan pencari kerja dapat digunakan sebagai cerminan peningkatan pengangguran, hal tersebut dikarenakan di

Kabupaten Labuhanbatu kenaikan jumlah tenaga kerja diikuti juga dengan kenaikan pencari kerjayang mengakibatkan pengurangan yang tidak terlalu besar, namun permasalahan pengangguran ini dapat diatasi, dilihat dari kontribusi UKM yang mampu menyerap tenaga kerja rata-rata lebih dari 40 persen setiap tahunnya dari total penduduk yang bekerja, apabila terus dikembangkan UKM mampu menjadi wadah penyerapan tenaga kerja sebagai salah satu pengurangan pengangguran di Kabupaten Labuhanbatu. Berkembangnya investasi, jumlah penerimaan Pendapatan Asli Daerah dan jumlah usaha UKM Kabupaten Labuhanbatu saat ini, maka dapat memberi pengaruh yang besar terhadap jumlah tenaga kerja dan bisa dilihat perkembangan yang baik dalam mereduksi atau mengurangi jumlah pengangguran. Untuk lebih menarik bagi penulis dalam melihat bagaimana pengaruh investasi, penerimaan Pendapatan Asli Daerah dan jumlah Usaha UKM terhadap penyerapan tenaga kerja di Kabupaten Labuhanbatu, untuk itu penulis mengambil judul " Analisis Investasi UKM, Pendapatan Asli Daerah dan Jumlah UKM terhadap penyerapan Tenaga Kerja UKM di Kabupaten Labuahnbatu.

Perumusan masalah dilihat dari kontribusi UKM dalam perekonomian Kabupaten Labuhanbatu yang terus meningkatkan investasi, pendapatan asli daerah dan jumlah unit usaha UKM mampu menjadi salah satu sektor yang dapat memperdayakan masyarakat dalam kata lain meningkatkan penyerapan tenaga kerja dan mampu meminimalisir masalah pengangguran. Maka permasalahan yang akan mempengaruhi UKM dalam penyerapan tenaga kerja, dapat dirumuskan sebagai berikut; 1 . Seberapa besar pengaruh variabel investasi UKM, PAD dan jumlah unit usaha UKM terhadap variabel penyerapan tenaga kerja UKM di Kabupaten Labuhanbatu secara simultan. 2. Seberapa besar pengaruh variabel investasi UKM, PAD dan jumlah unit usaha UKM terhadap variabel penyerapan tenaga kerja UKM Di Kabupaten Labuhanbatu secara parsial.

\section{LANDASAN TEORI}

Penyerapan tenaga kerja adalah banyaknya orang yang dapat tertampung untuk bekerja pada suatu unit usaha atau lapangan pekerjaan. Penyerapan tenaga kerja ini akan menampung semua tenaga kerja apabila unit usaha atau lapangan pekerjaan yang tersedia mencukupi atau seimbang dengan banyaknya tenaga kerja yang ada. Adapun lapangan pekerjaan adalah bidang kegiatan usaha atau instansi di mana seseorang bekerja atau pernah bekerja (BPS, 2003).

Menurut UU No. 13 tahun 2003 Bab I pasal 1 ayat 2 disebutkan bahwa tenaga kerja adalah setiap orang yang mampu melakukan pekerjaan guna menghasilkan barang dan atau jasa baik untuk memenuhi kebutuhan sendiri maupun untuk masyarakat (Subijanto, 2011). Secara garis besar penduduk suatu negara dibedakan menjadi dua kelompok, yaitu tenaga kerja dan bukan tenaga kerja. Sedangkan menurut Simanjuntak dalam bukunya "Pengantar Ekonomi Sumber Daya Manusia" tenaga kerja adalah penduduk yang sudah atau sedang bekerja, yang sedang mencari pekerjaan, dan yang melaksanakan kegiatan lain seperti bersekolah dan mengurus rumah tangga.

Pasar tenaga kerja di Indonesia dapat dibedakan atas sektor formal dan informal. Sektor formal mencakup perusahaan yang mempunyai status hukum, pengakuan dan izin resmi serta umumnya berskala besar. Sebaliknya sektor informal merupakan sektor dengan kegiatan usaha umumnya sederhana, skala usha relative kecil, umumnya sektor informal tidak berbadan hukum, usaha sektor informal sangat beragam. Dalam hal ini UKM merupakan salah satu indikasi dari sektor informal (Raselawati, 2011:44). 
Investasi adalah penanaman modal untuk satu atau lebih aktiva yang dimiliki biasanya berjangka panjang dengan harapan mendapat keuntungan dimasa yang akan datang sebagai kompensasi secara professional atas penundaan konsumsi, dampak inflasi dan resiko yang ditanggung (Raselawati, 2011: 28). Sedangkan menurut Sukirno (2005: 121), investasi didefinisikan sebagai pengeluaran-pengeluaran untuk membeli barang-barang modal dan peralatan-peralatan produksi dengan tujuan untuk mengganti dan terutama menambah barang modal dalam perekonomian yang akan digunakan untuk memproduksi barang dan jasa dimasa depan.

Investasi adalah suatau kegiatan penanaman modal pada berbagai kegiatan ekonomi (produksi) dengan harapan untuk memperoleh keuntungan dimasa-masa yang akan datang (Kementerian Koperasi dan UKM 2011).

Pendapatan Asli Daerah (PAD) Menurut Halim (2002), dalam bukunya yang berjudul "Akuntansi Sektor Publik dan Akuntansi Keuangan Daerah" beliau menyatakan bahwa Pendapatan Asli Daerah (PAD) merupakan semua penerimaan daerah yang berasal dari sumber ekonomi asli daerah. Menurut Mardiasmo (2002) pendapatan asli daerah adalah penerimaan yang diperoleh dari sektor pajak daerah, restribusi daerah, hasil perusahaan milik daerah, hasil pengelolaan kekayaan daerah yang dipisahkan dan lain-lain pendapatan asli daerah.

Menurut Matz (2003) dalam Wicaksono (2010), dengan adanya peningkatan investasi pada suatu industri, juga akan meningkatkan penyerapan tenaga kerja. Hal ini dikarenakan oleh dengan adanya peningkatan investasi maka akan meningkatkan jumlah perusahaan yang ada pada industri tersebut. Peningkatan jumlah perusahaan maka akan meningkatkan jumlah output yang akan dihasilkan sehingga lapangan pekerjaan meningkat dan akan mengurangi pengangguran atau dengan kata lain akan meningkatkan penyerapan tenaga kerja. Sedangkan menurut Karib (2012: 61) jumlah unit usaha erat dengan penyerapan tenaga kerja pada sektor industri, dilihat dari terus meningkatnya jumlah usaha.

\section{LANDASAN EMPIRIK}

Wiratno Bagus Suryono (2010) “Analisis Pengaruh Pendapatan Asli Daerah, Tingkat Investasi dan Tenaga Kerja terhadap PDRB Jawa Tengah" penelitian ini bertujuan untuk mengetahui pengaruh pendapatan asli daerah dan investasi terhadap tenaga kerja dan terhadap PDRB di Jawa tengah. Nenik Woyanti dan Ayu Wafi Lestari (2011) "Pengaruh Jumlah Usaha, Nilai Investasi, dan Upah Minimum Terhadap Permintaan Tenaga Kerja Pada Industri Kecil dan Menengah Di Kabupaten Semarang”. Model estimasi yang digunakan dalam penelitian ini adalah Analisis regresi berganda. Abdul Karib (2012) "Analisis Pengaruh Produksi, Investasi, dan Unit Usaha Terhadap Penyerapan Tenaga Kerja Pada Sektor Industri Sumatera Barat", model yang telah di rumuskan akan di regres untuk mengestimasi persamaan tersebut dengan menggunakan metode Ordinairy Least Square (OLS), dengan menggunakan data sekunder dalam menganalisis yang diperoleh dari berbagai sumber, seperti Badan Pusat Statistik (BPS), Dinas perindustrian dan perdagangan Sumatera Barat (Sektor Industri dalam angka 1997- 2008). Rizky Eka Putra (2012)“Pengaruh Nilai Investasi, Nilai Upah, dan Nilai Produksi Terhadap Penyerapan Tenaga Kerja Pada Industri Mebel di Kecamatan Pedurungan Kota Semarang", variabel penelitian adalah nilai investasi, nilai upah, nilai produksi sebagai variabel bebas dan penyerapan tenaga kerja sebagai variabel terikat. Johana Rosmalia, Rusdiah Iskandar, Fitriadi (2014) "Pengaruh investasi tenaga kerja terhadap PDRB dan PAD Kota Balikpapan" penelitian ini bertujuan untuk mengetahui bagaimana pengaruh investasi tenaga kerja terhadap PDRB dan PAD Kota Balikpapan 


\section{HIPOTESIS}

Diduga investasi UKM, penerimaan Pendapatan Asli Daerah dan Jumlah UKM berpengaruh positif signifikan terhadap penyerapan tenaga kerja UKM yang ada di Kabupaten Labuhanbatu.

\section{METODE PENELITIAN \\ Uji Asumsi Klasik}

Uji kepenuhan asumsi klasik adalah uji yang digunakan untuk melihat apakah terdapat suatu penyimpangan asumsi klasik dalam model regresi linier berganda (Gujarati, 2003).uji asumsi klasik dalam penelitian ini meliputi uji multikolinieritas, hetereskedastisitas dan autokorelasi.

Dari data sekunder yang ada akan diambil merupakan variabel yang mempengaruhi penyerapan tenaga kerja UKM di kabupaten Labuhanbatu. Penyerapan tenaga kerja merupakan variabel dependen yang dilambangkan dengan Y. Variabel bebas atau variabel independen dalam

penelitian ini adalah variabel yang mempengaruhi penyerapan tenaga kerja yaitu Investasi (X1), Pendapatan Asli daerah (X2), Jumlah Unit UKM (X3). Sumber data yang digunakan dalam penelitian ini adalah data sekunder. Data diperoleh dari buku statitik Kabupaten Labuhanbatu dalam angka dan data jurnal terkait. Data yang digunakan dalam penelitian ini adalah data dari tahun 2007 sampai 2016. Analisis yang digunakan persamaan tunggal regresi berganda dengan fungsi logaritma atau logaritma natural ganda (Ln). Utomo (2007) mengungkapkan penggunaan persamaan tunggal regresi berganda dengan fungsi Double Natural Logaritma atau Logaritma Natural Ganda (Ln) dengan mengunakan teknikestimasi Ordinal Least Square (OLS) maka bentuk persamaannya seperti berikut :

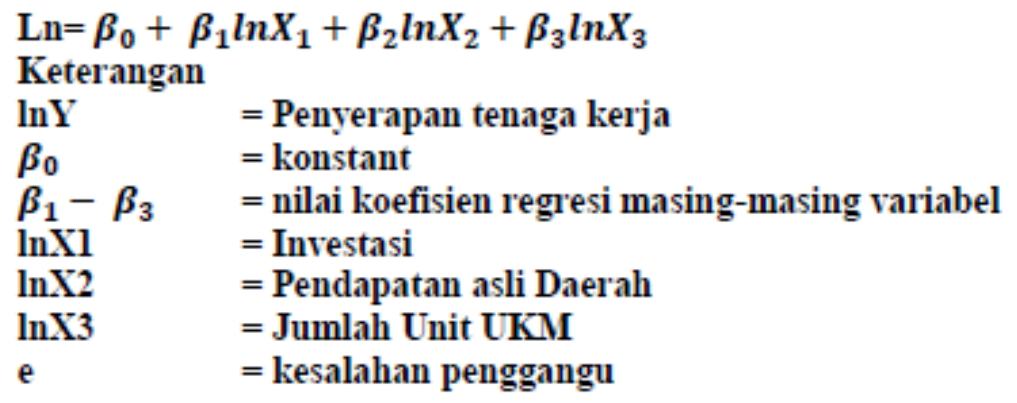

\section{Defenisi Operasional}

1. Penyerapan Tenaga Kerja UKM Penyerapan tenaga kerja adalah banyaknya orang yang dapat tertampung untuk bekerja pada suatu unit usaha atau lapangan pekerjaan. Penyerapan tenaga kerja ini akan menampung semua tenaga kerja apabila unit usaha atau lapangan pekerjaan yang tersedia mencukupi atau seimbang dengan banyaknya tenaga kerja yang ada. Satuan yang digunakan pada variabel ini adalah jiwa.

2. Investasi adalah suatau kegiatan penanaman modal pada berbagai kegiatan ekonomi (produksi) dengan harapan untuk memperoleh keuntungan (gain/benefit) dimasa-masa yangakan datang (Kementerian Koperasi dan UKM 2011). Satuan yang digunakan pada variabel ini adalah jutaan rupiah.

3. Pendapatan Asli Daerah adalah total Pendapatan Asli Daerah di Kabupaten Labuhanbatu setiap tahunnya selama waktu penelitian dihitung dalan jutaan Rupiah.

4. Jumlah Unit Usaha UKM Peningkatan jumlah perusahaan maka akan meningkatkan jumlah output yang akan dihasilkan sehingga lapangan pekerjaan meningkat dan akan mengurangi pengangguran atau dengan kata lain akan meningkatkan penyerapan tenaga kerja. Satuanyang digunakan pada variabel ini adalah unit 


\section{Uji Validitas Pengaruh (Uji t)}

Untuk menguji pengaruh dari variabel independen terhadap variabel dependen digunakan uji t. Uji statistik ini bertujuan untuk mengetahui besarnya pengaruh masing-masing variabel independen terhadap variabel dependen secara dua sisi (two tail).

\section{Uji F}

Uji F dilakukan untuk mengetahui apakah model yang digunakan eksis atau tidak.

\section{Koefisien Determinasi (Uji R2)}

Nilai koefisien determinasi R2 menunjukan prosentase total variasi variabel dependen yang dapat dijelaskan oleh variabel independen dalam model.

\section{HASIL PENELITIAN DAN PEMBAHASAN}

\section{a. Uji Asumsi Klasik}

\section{1). Uji Multikolinieritas}

Untuk menguji multikolinearitas antar variabel bebas, peneliti menggunakan uji VIF (Variance InflationFactor) dengan bantuan program SPSS versi 17. Uji multikolinearitas dilakukan dengan melihat tolerance value dan variance inflationfactor (VIF). Multikolinearitas terjadi bila nilai VIF diatas nilai 10 atau tolerance value dibawah 0,10 . Multikolinearitas tidak terjadi bila nilai VIF dibawah nilai 10atau tolerance value diatas 0,10 . (Santoso, 2007) Hasil uji multikolinearitas ditunjukkan pada tabel berikut:

\section{Tabel 1.2 Hasil Uji Multikolinearitas}

\begin{tabular}{|l|l|r|}
\hline \multirow{3}{*}{ model } & \multicolumn{2}{|l|}{$\begin{array}{l}\text { Collinearity } \\
\text { Statistics }\end{array}$} \\
\cline { 2 - 3 } & Tolerance & VIF \\
\hline I & .367 & 2.723 \\
\hline PAD & .124 & 8.049 \\
\hline JU & .101 & 9.921 \\
\hline
\end{tabular}

Berdasarkan Tabel di atas dapat dilihat bahwa besarnya nilai inflation factor (VIF). Multikolinearitas terjadi bila nilai VIF diatas nilai 10 atau tolerance value dibawah 0,10.dari metode ini dapat disimpulkan bahwa dalam model persamaan tersebut tidak ditemukan adanya multicollinearity. 


\section{2). Uji Heterokedastisitas}

\section{Tabel 1.3 Hasil Uji Heterokedastisitas}

Sumber : Hasil Pengolahan SPSS versi 20

\begin{tabular}{|l|l|l|}
\hline Model & T & Sig. \\
\hline (Constant) & .734 & .490 \\
\hline I & -1.005 & .354 \\
\hline PAD & -.368 & .726 \\
\hline JU & .582 & .582 \\
\hline
\end{tabular}

Pengujian heteroskesdastisitas berdasarkan output di atas diketahui bahwa nilai signifikasi variabel investasi UKM (X1) sebesar 0.354, variabel PAD (X2) sebesar 0.726 dan variabel jumlah unit UKM sebesar 0.582 lebih besar dari 0.05 artinya tidak terjadi heteroskedastisitas kesimpulannya tidak terdapat masalah heteroskedastisitas dalam model.

\section{3). Uji Autokorelasi}

\section{Tabel 1.3 Hasil Uji Autokorelasi}

\begin{tabular}{|l|l|l|}
\hline \multirow{3}{*}{ Model } & $\begin{array}{l}\text { Std. Error of the } \\
\text { Estimate }\end{array}$ & $\begin{array}{l}\text { Durbin- } \\
\text { Watson }\end{array}$ \\
\hline 1 & 012 & 1.840 \\
\hline
\end{tabular}

Sumber : Hasil Pengolahan SPSS versi 20

Berdasarkan output di atas, diketahui nilai DW 1.840 lebih besar dari batas atas $(\mathrm{du})$ yakni 0.5253 dan kurang dari 2.0163 ( 4-du) 4-1,0.5253=2.0163. sehingga dapat disimpulkan bahwa tidak terjadi autokorelasi pada pengujian model.

\section{b. HasiL Regresi Linear Berganda}

Berdasarkan hasil pengolahan data dengan menggunakan program SPSS 20, dengan pendekatan model analisis regresi linier berganda metode Ordinary Least Square (OLS). Hasil persamaan tersebut bila ditulis dalam persamaan linier menjadi sebagai berikut : 
Tabel 1.4 Hasil Estimasi Data

\begin{tabular}{|l|l|l|l|}
\hline Variabel & Koefisien & t-stat & Prob. \\
\hline Konstanta & 0.181 & 0.186 & 0.859 \\
\hline Investasi & 0.209 & 4.130 & $0.006^{*}$ \\
\hline PAD & 0.021 & 1.055 & 0.332 \\
\hline Jumlah UKM & 0.478 & 3.212 & $0.018^{*}$ \\
\hline R-squared & & 0.983 & \\
\hline Adjusted R-squared & & 0.975 \\
\hline F-statistic & & 118.116 \\
\hline Prob(F-statistic) & \multicolumn{3}{|c|}{0.000} \\
\hline
\end{tabular}

Keterangan $5 \%{ }^{*}=$ signifikan

Sumber : Hasil Pengolahan SPSS versi 20

Hasil analisis regresi diatas dapat ditulis kebentuk persamaan linier menjadi:

Ln PTK = - 0.181 + 0,209 INV + 0,021 PAD + 0,478 JU

Dari tabel diatas diketahui bahwa variabel investasi dan jumlah ukm memiliki pengaruh signifikan terhadap penyerapan tenaga kerja UKM di Kabupaten Labuhanbatu. Variabel PAD tidak

tidak memiliki pengaruh signifikan terhadap penyerapan tenaga kerja UKM di Kabupaten Labuhanbatu.

c. Analisis Pengaruh Investasi UKM, Pendapatan Asli Daerah dan Jumlah Unit Usaha UKM Terhadap Penyerapan Tenaga Kerja UKM di Kabupaten Labuhanbatu (secara parsial).

Pengujian ini dilakukan untuk mengetahui apakah variabel bebas (Investasi UKM, Pendapatan Asli Daerah dan Jumlah Unit Usaha UKM) berpengaruh secara parsial terhadap variabel terikat (Penyerapan Tenaga Kerja UKM) dan seberapa besar pengaruhnya secara parsial, yaitu dengan membandingkan nilai t-statistik masing masing variabel dengan nilaidalam menolak atau menerima hipotesis. Pada tingkat kepercayaan $\alpha=5 \%, \mathrm{df}=6$, maka diperoleh 2.44691. Berdasarkan hasil regresi pada tabel, maka kita dapat menentukan hipotesis sebagai berikut :

Variabel Investasi, t-statistik > t-tabel yang berarti Ho ditolak. 
Variabel PAD , t-statistik < t-tabel yang berarti Ho diterima.

Variabel Jumlah Unit Usaha UKM, t-statistik > t-tabel yang berarti Ho ditolak.

Pada variabel investasi UKM memiliki hasil yang berpengaruh terhadap penyerapan tenaga kerja UKM di Kabupaten Labuhanbatu. Hal ini dijelaskan berdasarkan hasil estimasi dari nilai t-statistik $(4.130)<$ ttabel $(2.44691)$ dengan tingkat keyakinan sebesar $95 \%(\alpha=$ 5\%). Nur Hasanah Bustami (2016) jumlah unit UMKM, PDB UMKM dan investasi secara simultan berpengaruh terhadap penyerapan tenaga kerja. Hampir semua ahli ekonomi menekankan arti pentingnya pembentukan investasi sebagai penentu utama pertumbuhan ekonomi karena investasi merupakan komponen utama dalam menggerakkan roda perekonomian. Dengan demikian sudah terlihat bahwa investasi merupakan variabel yang sangat penting dalam meningkatkan penyerapan tenaga kerja

Hasil estimasi diatas menjelaskan bahwa variabel PAD memiliki hasil yang tidak berpengaruh terhadap penyerapan tenaga kerja UKM di Kabupaten Labuhanbatu. Hal ini dikatahui dari nilai t-statistik (1.055) > t-tabel (2.44691) dengan tingkat keyakinan sebesar 95\% $(\alpha=5 \%)$. Menurut Karib (2012), jadi dapat di simpulkan bahwa Pendapatan Asli Daerah memiliki pengaruh yang tidak signifikan terhadap tingkat jumlah Tenaga Kerja di Kabupaten Labuhanbatu pada taraf signifikansi $a=0,025$. Persamaan regresi menunjukkan angka tidak signifikan untuk koefisien $\mathrm{x}$ dan hal ini tidak sesuai dengan harapan teoritik bahwa Pendapatan Asli Daerah memiliki pengaruh yang signifikan terhadap tenaga kerja.

Hasil estimasi pada variabel jumlah unit usaha UKM menyimpulkan bahwa terdapat pengaruh yang signifikan dan positif terhadap penyerapan tenaga kerja UKM di kabupaten Labuhanbatu. Hal ini diketahui dari nilai t-statistik (3.212) > t-tabel (2.44691) dengan tingkat keyakinan sebesar 95\% $(\alpha=5 \%)$. Hal tersebut menjelaskan bahwa jika jumlah unit usaha UKM meningkat maka penyerapan tenaga kerja pada sektor UKM juga meningkat. Pada tabel estimasi koefisien regeresi variabel Jumlah unit usaha UKM sebesar 0,478, berarti setiap peningkatan unit usaha UKM sebesar 1 persen, maka dapat menyebabkan kenaikan penyerapan tenaga kerja UKM sebesar 0,478 persen, cateris paribus. Hal ini diperkuat oleh penelitian Tejasari (2008), yang mengatakan bahwa peningkatan jumlah usaha sama artinya dengan menambah jumlah lapangan usaha sehingga kesempatan kerja akan terbuka. Kondisi tersebut akan menyerap tenaga kerja yang tersedia pada jumlah unit usaha baru yang membutuhkan sumber daya manusia untuk pengelolaannya.

\section{d. Analisis Pengaruh Investasi UKM, PAD dan Jumlah Unit Usaha UKM Terhadap Penyerapan Tenaga Kerja UKM di Kabupaten Labuhanbatu (secara simultan).}

Pengujian ini dilakukan untuk mengetahui apakah variabell bebas berpengaruh secara simultan terhadap variabel terikat dan seberapa besar pengaruhnya secara simultan, maka digunakan uji $\mathrm{F}$ dengan membandingkan nilai F-statistik dengan nilai F-tabel dalam menolak atau menerima hipotesis. Pada tingkat kepercayaan $\alpha=5 \%, 1=4,2=10$, dan nilai F-statistik 118.116. Berdasarkan hasil estimasi nilai F-statistik (118.116) > F-tabel (3.48), maka Ho ditolak yang artinya variabel bebas (Investasi UKM, PAD dan Jumlah Unit Usaha UKM) berpengaruh signifikan secara simultan terhadap variabel terikat (Penyerapan Tenaga Kerja UKM) pada tingkat kepercayaan 95 persen.

\section{e. Uji Koefisien Determinasi (Adjusted R-squared)}

Berdasarkan hasil pengolahan data pada tabel nilai adjusted $R$ squared adalah sebesar 0.983. Hal ini menunjukan bahwa 97,5 persen penyerapan tenaga kerja pada sektor UKM di Kabupaten Labuhanbatu dapat dijelaskan oleh Investasi UKM, PAD dan Jumlah unit usaha UKM. Sedangkan 0,05 persen variabel penyerapan tenaga kerja pada sektor UKM dijelaskan oleh variabel lain yang tidak diteliti dalam penelitian ini. 


\section{PENUTUP}

\section{Kesimpulan} berikut :

Berdasarkan hasil analisis dan penelitian, maka dapat diperoleh kesimpulan sebagai

Berdasarkan hasil estimasi data estimasi dijelaskan bahwa secara simultan Investasi UKM, PAD dan jumlah unit usaha UKM berpengaruh signifikan terhadap penyerapan tenaga kerja sektor UKM di Kabupaten Labuhanbatu pada tahun 2007 sampai 2016 pada tingkat kepercayaan 95 persen.

Secara parsial hasil estimasi data panel dengan menjelaskan bahwa PAD tidak berpengaruh signifikan terhadap penyerapan tenaga kerja sektor UKM di Kabupaten Labuhanbatu pada tahun 2007 sampai 2016. Sedangkan Investasi UKM dan jumlah unit usaha berpengaruh signifikan dan positif terhadap penyerapan tenaga kerja sektor UKM di Kabupaten Labuhanbatu pada tahun 2007 sampai 2016.

\section{Saran}

Berdasarkan hasil analisis dan penelitian, maka saran yang dapat diberikan oleh penulis adalah sebagai berikut :

Kontribusi UKM dalam investasi UKM Pemerintah daerah diharapkan dapat meningkatkan investasi melalui kebijakan menjaga stabilitas ekonomi dengan menjaga iklim bisnis yang kondusif, politik dan keamanan dalam negeri, memperbaiki sarana dan prasarana infrastruktur yang menunjang serta mempermudah peraturan dalam berinvestasi sehingga dapat meningkatkan kesempatan kerja.

Salah satu terobosan yang perlu di lakukan oleh pemerintah Kabupaten Labuhanbatu dalam pengelolaan dana penerimaan Pendapatan Asli Daerah adalah melakukan hubungan baik dengan pemerintah Pusat dan para investor, agar supaya dana penerimaan pendapatan asli daerah akan lebih meningkat dan dapat berjalan lancar sesuai dengan yang di harapkan. menjaga agar stabilitas fiskal tetap terkendali dan kemampuan untuk membuat sejumlah terobosan atau inovasi yang efektif untuk memperbanyak lapangan pekerjaan guna mencegah pengangguran dan menambah jumlah penyerapan tenaga kerja

Jumlah unit usaha UKM yang lebih dominan dibanding usaha besar, menjadi unggulan UKM dalam penciptaan lapangan pekerjaan. Hal ini memaksa pemerintah agar meningkatkan investasi pada sektor padat karya agar keunggulan jumlah unit usaha UKM yang dominan dapat berimplikasi dalam menciptakan lapangan pekerjaan yang berorientasi memaksimalkan sumber daya manusia yang ada. 


\section{DAFTAR PUSTKA}

Abdul Halim, (2002). Akuntansi Sektor Publik akuntansi Keuangan Daerah Edisi pertama, Salemba empat, Jakarta

Badan Pusat Statistik Labuhan Batu dalam Angka Tahun 2006- 2016

Kementerian Koperasi dan UKM. 2011. Statistik Usaha Mikro, Kecil dan Menengah Tahun2010- 2011. Kementerian Negara KUKM, Jakarta.

Mardiasmo. (2002). Akuntansi Sektor Publik. Penerbit Andi. Yogyakarta.

Mankiw, Gregory. N. (2007). Pengantar Ekonomi Makro, Edisi kelima. Salemba Empat. Jakarta.

Partomo, T. dan A. Soejodomo. (2004). Ekonomi Skala Kecil/Menengah dan Koperasi. Ghalia. Jakarta

Todaro, M. (2006).Pengembangan Ekonomi Dunia Ketiga.Edisi Kedelapan. Jakarta:

Penerbit Erlangga ,

Santoso,Singgih,(2007) Menguasai Statistik di era Reformasi dengan SPSS 15. PT Alex Media, Komputindi. Jakarta

Simanjuntak, Payaman J. (2005). Pengantar Ekonomi Sumber Daya Manusia. Penerbit: FE-UI, Jakarta

Sukirno, Sadono. (2005). “Makro Ekonomi; Teori Pengantar”, Edisi ketiga. Jakarta: PT. Raja Grafindo Persada

Subyanto. (2011). Analisis Regresi dan Uji Hipotesis. Yogyakarta: Caps

Tambunan, Tulus.( 2002). Usaha Kecil dan Menengah di Indonesia, Beberapa Isu Penting. Jakarta: Salemba Empat.

Tejasari, Maharani. (2008). Peran Sektor Usaha Kecil dan Menengah dalam PenyerapanTenaga Kerja dan Pertumbuhan Ekonomi di Indonesia. Institut Pertanian Bogor.

Utomo, Prihadi, Y. (2011). Buku Praktek Komputer Statistik II : Eviews. Fak. Ekonomi. Universitas Muhammadiyah Surakarta

JurnalHeatubun, B Adolf. (2008). Potensi Jumlah Usaha Kecil dan Menengah dalam Peranannya Menstimulasi Perekonomian. Jurnal : Jurnal Organisasi dan Manajemen, Volume 4, No1, $\quad$ Maret @008, 34-35. 